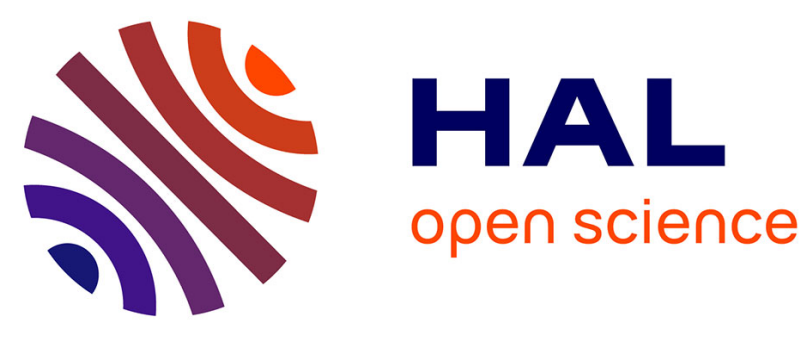

\title{
Occurrence and identification of microplastics in beach sediments from the Hauts-de-France region
}

Périne Doyen, Ludovic Hermabessiere, Alexandre Dehaut, Charlotte Himber, Marion Decodts, Thiefaine Degraeve, Léna Delord, Marie Gaboriaud, Pauline Moné, Jade Sacco, et al.

\section{To cite this version:}

Périne Doyen, Ludovic Hermabessiere, Alexandre Dehaut, Charlotte Himber, Marion Decodts, et al.. Occurrence and identification of microplastics in beach sediments from the Hauts-de-France region. Environmental Science and Pollution Research, 2019, 26, pp.28010-28021. 10.1007/s11356-019-060278. anses- 02558662

\section{HAL Id: anses-02558662 \\ https://hal-anses.archives-ouvertes.fr/anses-02558662}

Submitted on 29 Apr 2020

HAL is a multi-disciplinary open access archive for the deposit and dissemination of scientific research documents, whether they are published or not. The documents may come from teaching and research institutions in France or abroad, or from public or private research centers.
L'archive ouverte pluridisciplinaire HAL, est destinée au dépôt et à la diffusion de documents scientifiques de niveau recherche, publiés ou non, émanant des établissements d'enseignement et de recherche français ou étrangers, des laboratoires publics ou privés. 
1 Occurrence and identification of microplastics in beach sediments from the Hauts-de-France

2 region

3

4 Périne Doyen ${ }^{1, \mathrm{a}, \mathrm{c},{ }^{*},}$, Ludovic Hermabessiere ${ }^{1, \mathrm{~b}}$, Alexandre Dehaut ${ }^{\mathrm{b}}$, Charlotte Himber ${ }^{\mathrm{b}}$, Marion Decodts ${ }^{\mathrm{c}}$,

5 Thiefaine Degraevec ${ }^{c}$, Léna Delord ${ }^{c}$, Marie Gaboriaud ${ }^{c}$, Pauline Monéc, Jade Sacco ${ }^{c}$, Eric Tavernier ${ }^{\mathrm{c}, \mathrm{d}}$, Thierry

6 Grard $^{\mathrm{a}}$, Guillaume Duflos ${ }^{\mathrm{b}}$.

7

$8 \quad{ }^{1}$ P. Doyen and L. Hermabessiere share co-authorship of this article

9 a. Univ. Littoral Côte d'Opale, USC Anses, EA 7394 - ICV - Institut Charles Viollette, 62200 Boulogne-sur10 Mer, France.

11 b Anses, Laboratoire de Sécurité des Aliments, Boulevard du Bassin Napoléon, 62200 Boulogne-sur-Mer,

12 France.

13 c IUT Littoral Côte d'Opale, Boulevard du Bassin Napoléon, 62200 Boulogne-sur-Mer, France.

14 d Univ. Littoral Côte d'Opale, Univ. Lille, CNRS, UMR 8187, LOG, Laboratoire d'Océanologie et de 15 Géosciences, 62930 Wimereux, France

16

17 * Corresponding author: E-mail address: perine.doyen@ univ-littoral.fr.

Published in Environmental Science and Pollution Research and available online at 


\section{Abstract}

The present work was carried out to quantify microplastics (MP) from three sandy beaches along the Côte d'Opale coastline located in the Hauts-de-France region of northern France. Three different study sites located along the English Channel were investigated due to different levels of anthropopression and hydrodynamic conditions. Sediments were collected at three different tide lines: high tide line (HTL), middle of the intertidal zone (IZ), and low tide line (LTL) to investigate the effects of tide line on microplastic contamination. Particles and fibers were counted and colors were recorded; polymer identification was then performed using pyrolysisgas chromatography-mass spectrometry (Py-GC/MS). Particles and fibers abundance ranged from $23.4 \pm 18.9$ to $69.3 \pm 30.6$ items $\mathrm{kg}^{-1}$ dry weight sediment, with a trend towards fiber predominance, were observed. No difference in particles and fibers abundance was found between the different beaches and tide lines, except for Boulogne-sur-Mer, where the particle number was significantly different between tide lines. Major polymers identified were polyethylene $(36.6 \%)$ and polypropylene $(10.7 \%)$. This citizen science project provided preliminary data about the abundance and polymeric nature of MP along the Côte d'Opale coastline.

\section{Keywords}

Microplastic, sediment, beach, tide line, identification, Py-GC/MS 


\section{Introduction}

The production of plastics has grown continuously since the 1950 s, with an increase of $37 \%$ over the last decade (PlasticsEurope 2017). Most plastics are extremely durable and could persist from decades to centuries in their initial forms (Hopewell et al. 2009). Due to their physical properties, plastics are able to contaminate the environment on a global scale. Plastic particles smaller than $5 \mathrm{~mm}$ are defined as microplastics (MP) according to the United States National Oceanic and Atmospheric Administration (NOAA) (Arthur et al. 2009). The first record of MP, named spherules, in marine surface water dates back to the 1970s (Carpenter et al. 1972). The most prominent types of MP identified in the marine environment include beads, pellets, irregular fragments, and fibers. Large plastic debris can be fragmented by different degradation mechanisms such as physical, photolytic and chemical processes leading to secondary MP (Browne et al. 2007). Following these processes, MP are distributed throughout the sediment (Kedzierski et al. 2016), the water column (Bagaev et al. 2017; Chubarenko et al. 2016), and the deep-sea (Van Cauwenberghe et al. 2013b). Indeed, MP will tend to be present either on the sea surface or in the water column, depending on their densities. Nonetheless, beyond the theoretical repartition, some parameters like size and fouling can lead to the sink or oscillation of low-density polymers throughout the water column (Kooi et al. 2017). The presence of MP in sediments of various origins was highlighted many years ago (Thompson et al. 2004). Since this observation, numerous studies have demonstrated the abundance of MP in marine sediments worldwide (Besley et al. 2017; Lusher 2015; Van Cauwenberghe et al. 2015). However, few authors have been interested in MP occurrence in the sediments of beaches along the English Channel (Ashton et al. 2010; Browne et al. 2010; Browne et al. 2011; Endo et al. 2013; Holmes et al. 2012; Ogata et al. 2009).

The challenges of environmental protection have now led to greater communication between scientists and the local population. The general public can participate in scientific projects in order to discover the benefits of research, and this enables scientists to obtain large amounts of data. These projects are called "Citizen Science Projects" and involve volunteer participants from schoolchildren to adults, who participate in data collection, data processing, or even design of project protocols (Dickinson et al. 2012). These collaborative efforts have for example made it possible to study the MP in beach sediment across Europe (Lots et al. 2017), in an American mixed land-use river (Barrows et al. 2018), and in Atlantic cod (Liboiron et al. 2016). In the present collaborative framework, five students from the University Institute of Technology (Université du Littoral Côte d'Opale) located in Boulogne-sur-Mer (France) participated in an environmental project. As no data have been published about MP quantification and characterization along the Côte d'Opale coastline of the English Channel, 
this study was carried out in order to fill this gap. The aims of the present study were to (1) quantify and characterize for the first time MP abundance from three beaches along the Côte d'Opale coastline; (2) observe whether the hydrodynamic characteristics and human population of these sampling sites impacted this abundance; (3) study the influence of tide lines on MP accumulation, and (4) identify polymers using pyrolysisgas chromatography-mass spectrometry (Py-GC/MS).

\section{Materials and Methods}

\subsection{Study Areas}

Samples were collected from three beaches: Ambleteuse, Boulogne-sur-Mer and Berck, along the Côte d'Opale coastline in the Hauts-de-France region (Figure 1). These three locations are touristic beaches of the English Channel but Ambleteuse is very close to the mixture of waters between the North Sea and the English Channel. These three beaches presented different hydrodynamic and anthropopression conditions. Ambleteuse is a village of 1,807 inhabitants (INSEE 2015) near the North Sea and located in an environmental protection zone (Vérin et al. 2018). The mouth of the Slack River is located near the beach. This $21.8 \mathrm{~km}$ long river has an annually water flow of $0.646 \mathrm{~m}^{3} \cdot \mathrm{s}^{-1}$ and its watershed surface is $156 \mathrm{~km}^{2}$ (Ministère de l'écologie 2018c; Service Sandre Eau de France 2012b). Boulogne-sur-Mer is a town of 42,366 inhabitants (INSEE 2015) whose beach is close to an urban and industrial area, including the largest European center for seafood processing and is protected by a dike. A bathing ban, linked to microbiological contamination, is very common on this beach located near the mouth of the Liane River. This $38.2 \mathrm{~km}$ long river presents a watershed of $271 \mathrm{~km}^{2}$ and an annual water flow of $2.99 \mathrm{~m}^{3} \cdot \mathrm{s}^{-1}$ (Ministère de l'écologie 2018b; Service Sandre Eau de France 2012a). Berck is a city of 14,509 inhabitants (INSEE 2015) and its beach is close to a protected environment as a part of the Berck sand dunes and the north shores of Authie Bay, which are classified as protected areas by the Conservatory of the Coast (Inventaire National du Patrimoine Naturel 2018). Moreover, samples on this beach were collected near the estuary of the Authie, which is a $108.2 \mathrm{~km}$ long river with an annual water flow of $7.8 \mathrm{~m}^{3} \cdot \mathrm{s}^{-1}$ and a watershed of 1,156 km² (Ministère de l'écologie 2018a; Service Sandre Eau de France 2012c).

\subsection{Preparation of material and prevention of contamination}

Water and $70 \%$ ethanol were filtered once through a Whatmann GF/A, $1.6 \mu \mathrm{m}$ glass microfiber filter (VelizyVillacoublay, France). A fully saturated salt solution was prepared adding $1 \mathrm{~L}$ of filtered demineralized water with $360 \mathrm{~g}$ of Carlo Erba Reagents sodium chloride ( $\mathrm{NaCl})$ (Val de Reuil, France). The density of this saline solution was $1.2 \mathrm{~g} \mathrm{~cm}^{-3}$. This $\mathrm{NaCl}$ solution was also filtered once through a GF/A, $1.6 \mu \mathrm{m}$ glass microfiber 
filter. Glass jars and their metals lids were previously washed following three steps: 1) rinsing with filtered demineralized water, 2) washing with filtered $70 \%$ ethanol, and 3) rinsing again with filtered demineralized water. Metal spoons used for sampling were also cleaned with the same process and packed in aluminum foils. Glass jars were prepared, weighed and the empty weights were recorded in order to subsequently obtain the sand weight. Four Petri dishes were put in different places in the laboratory during the extraction and counting processes in order to evaluate airborne contamination. In addition, cotton lab coats were worn during all steps of the analytical procedure (material preparation, filtration, counting, and isolation).

\subsection{Sampling, extraction and quantification of particles and fibers}

Five students supervised by a researcher collected the sediment samples on January $13^{\text {th }}$ and $14^{\text {th }}, 2017$ corresponding to a period of limited tourist activity and a tidal coefficient of 102 , in order to collect samples across the widest possible surface area along the beaches. For each site (see supporting information Table S1), sampling was done at three different tidal zones along the beach: the high tide line (HTL), the middle of the intertidal zone (IZ), and the low tide line (LTL). Metal spoons were used to scoop $(0.25 \mathrm{x} 0.25 \mathrm{~m})$ approximately the top $3 \mathrm{~cm}$ of beach sediment, which was immediately stored in glass jars. The samples were collected in triplicate and two meters separated each replicate at each tide line. A total of nine sediment samples per beach were analyzed. Glass jars were stored one week at $50^{\circ} \mathrm{C}$ in a Heraeus Type $\mathrm{T} 12$ stove (Thermo Scientific, Germany) to dry the sediments. Before the extraction of particles and fibers, the glass jars were weighed using a $0.01 \mathrm{~g}$ Sartorius CP4202S sensitivity analytical balance (Göttingen, Germany) to obtain the exact weight of dry sediment. An average of $1.5 \mathrm{~kg}$ of dry sediments were obtained and analyzed for each replicate at each tide line. The sediment samples were then sieved with a Retsch, AS200 Basic column (Eragny-sur-Oise, France) with sieves of 5, 2 and $1 \mathrm{~mm}$. In several samples, potential colored plastic particles, e.g. red or blue, were visually extracted from sieved sediments with tweezers and counted before the density separation. The MP density-based extraction from sediment was adapted from Laglbauer et al. (2014) and Lots et al. (2017). $500 \mathrm{~mL}$ of fully saturated salt solution ( $c f .2 .2)$ were added to $250 \mathrm{~g}$ of dry sediment and shaken by hand for 2 minutes. After a 24H decantation step, supernatants were filtered through GF/A, $1.6 \mu \mathrm{m}$ glass microfiber filters with a ThermoFisher Scientific Nalgene Vacuum Manifold (Montigny-le-Bretonneux, France), equipped with a Merck glass filter holder assembly with a $250 \mathrm{~mL}$ funnel, fritted base, cap and clamp (Fontenay-sous-Bois, France). For each supernatant, several filters were used to avoid clogging and to facilitate the observation of particles. The extraction process was performed once for each sample. The different controls and filters from the 27 sediment samples were examined using a Motic SMZ 140 binocular loupe (Richmond, Canada) with x10 magnification. 
When higher magnification was required, a Motic B1 Series stereomicroscope (Richmond, Canada) with up to x40 magnification was alternatively used to correctly differentiate the MP. They were counted and separated in two categories: 1) fibers, and 2) particles comprising: fragments, pellets, films, and foams. The colors were also recorded to display the proportions of the various observed colors. In addition, the colors of particles and fibers were compared between the controls and the samples. White, green, yellow, red and blue fibers were observed in controls, leading to the exclusion of these fiber colors in order to adjust the data for sample contamination. The abundance in a sediment sample was expressed as a number of items per kilogram dry weight sediment (items $\mathrm{kg}^{-1}$ d.w.).

\subsection{Polymer identification}

A sub-sampling of MP, excluding fibers, was analyzed following the Py-GC/MS method described by Dehaut et al. (2016). Briefly, the analysis cup containing the plastic was placed on the AS-1020E autosampler of a Frontier Lab EGA/PY3030D (Fukushima, Japan), before being pyrolyzed at 600 or $700^{\circ} \mathrm{C}$ for $1 \mathrm{~min}$. Pyrolysis products were directly injected, in split mode set at 40, 20 or 5 depending on item size, on a coupled Shimadzu GC-2010 device (Noisiel, France) and separated on a Restek RXi-5ms ${ }^{\circledR}$ column (60 m, $0.25 \mathrm{~mm}, 25 \mu \mathrm{m}$ thickness) (Lisses, France). The temperatures of the transfer line and of the injection port were both fixed at $300^{\circ} \mathrm{C}$. Helium was used as the carrier gas with a linear velocity of $40 \mathrm{~cm} \cdot \mathrm{s}^{-1}$. The oven program was set as follows: $5 \mathrm{~min}$ at $40^{\circ} \mathrm{C}$ increasing to $320^{\circ} \mathrm{C}$ at $20^{\circ} \mathrm{C} \cdot \mathrm{min}^{-1}$, maintained for $14 \mathrm{~min}$. Mass spectra were obtained by a Shimadzu QP2010Plus mass spectrometer coupled to the GC. Interface temperature was fixed at $300^{\circ} \mathrm{C}$, ion source temperature was set at $200^{\circ} \mathrm{C}$, ionization voltage was set at $70 \mathrm{eV}$ and a mass range extending from 33 to $500 \mathrm{~m} / \mathrm{z}$ was analyzed with a $2000 \mathrm{~Hz}$ scan speed.

Polymer identification was performed using F-Search software 4.3. Each pyrogram was firstly identified, querying against Frontier Lab's database, and then a custom database containing pre-acquired pyrograms with reference plastic samples. Identification was established based on the similarity percentage between average mass spectra. As advised by the Py-GC/MS supplier, a minimal value of $80 \%$ was necessary to certify proper identification. Secondly, if identification was not possible using F-Search and pyrolytic product was still present, the pyrogram was manually compared with the available literature (Tsuge et al. 2011), and characteristic compounds were searched in the pyrogram before being identified using the National Institute of Standards and Technology (NIST) 08 database.

\subsection{Statistical analyses}


All statistical analyses were performed using R software 3.4.2 (R Core Team 2017). Differences of item abundances were first assessed between beaches and then by zone for a given beach. For a given beach, the different abundances at the tide lines were compared considering the fibers, then the particles, and finally for all the items. The significance of the difference was studied using either one-way ANOVA or the Kruskal-Wallis test (KWT). ANOVA were solely carried out after careful control of residuals normality using a Shapiro-Wilks test and distribution homoscedasticity using Bartlett's test. When one of the hypotheses was not verified ( $p$-value $<0.05$ ), a non-parametric approach using a Kruskal-Wallis test was preferred. In a single case, a post-hoc test was performed after a Kruskal-Wallis test using the kruskal() function of the agricolae package 1.2.7 (De Mendiburu 2017), which is based on Fisher's least significant difference criterion and Bonferroni correction. Error bars indicated on bar charts represent the dispersion of data, illustrated by standard deviations. Bars tagged with different letters are significantly different with an error risk of 5\%.

\section{Results}

\subsection{Occurrence of particles and fibers in beach sediment}

\subsubsection{Regional variability of particles and fibers}

Overall, 184 filters were analyzed and 1692 items were detected from the sediments, which were separated in two categories: 185 particles and 1507 fibers. The average abundances of particles and fibers in beach sediments were $33.9 \pm 24.9$ items $\mathrm{kg}^{-1}$ dry weight (d.w.), $46.5 \pm 17.3$ items $\mathrm{kg}^{-1}$ d.w., and $48.1 \pm 40.9$ items $\mathrm{kg}^{-1}$ d.w. at Ambleteuse, Boulogne-sur-Mer, and Berck, respectively (Table 1). Overall, the total particles and fibers abundance was not different (ANOVA, $p>0.05$ ) between the three sites (Figure 2). This similarity was also observed between the three sites (Figure 3) for the abundance of particles (KWT, $p>0.05$ ) and fibers (KWT, $p>0.05)$.

\subsubsection{Line tide influence on particles and fibers variability}

The particle abundance between the three tides lines at Boulogne-sur-Mer was significantly different (KWT, $p=0.02$ ) with no particles at the low tide line, while the number of particles increased with the proximity to the high tide line (Figure 3A). Moreover, $15.3 \%$ of particles counted at the high tide line were black pellets (3.6 items $\mathrm{kg}^{-1}$ d.w.) (Figure S1). Nonetheless, no significant difference was highlighted between the three tidal heights at the other studied sites concerning the total particles and fibers abundance (ANOVA or KWT, $p>0.05$ ), but also the abundances of particles (KWT, $p>0.05$ ) and fibers (ANOVA, $p>0.05$ ) (Figure 3B). Overall on the three sites, fibers were the dominant form $(88.3 \%)$.

\subsection{Color considerations}


Among the particles, a maximum of nine colors were counted at Boulogne-sur-Mer and Ambleteuse, while seven colors were found at Berck (Figure 4A). White, green, yellow, red and blue fibers were excluded in this study as they were also observed in controls. Despite this exclusion, the same fiber color profiles were observed in beach sediments with a majority of black fibers (range 74 to $80 \%$ ) followed by pink (9 to $11 \%$ ) (Figure $4 \mathrm{~B}$ ).

\subsection{Particles identification}

Among the 185 particles found in this study, only 93 particles were analyzed $(50.3 \%)$ and $68.8 \%$ of these subsample particles (64 items) were successfully identified as plastic particles (Figure 5). One item (1.1\%) presented a pyrogram with peaks matching with rubber identification. Seven polymers were identified: polyethylene (PE; 34 items; $36.6 \%$ ), polypropylene (PP; 10 items; $10.7 \%$ ), polystyrene (PS; 7 items; $7.5 \%$ ), polyethylene terephthalate (PET; 3 items; $3.25 \%$ ), polyvinylchloride (PVC; 3 items, $3.25 \%$ ), PE/PP (6 items; $6.4 \%)$, and acrylonitrile butadiene styrene (ABS; 1 item; $1.1 \%)$.

\section{Discussion}

\subsection{Occurrence of particles and fibers in beach sediment}

This student-based citizen science project helped to gather evidence on MP contamination of three beaches along the Côte d'Opale coastline. The contribution of citizen science has, for example, already been reported to study marine litter (Hidalgo-Ruz and Thiel 2015; Nelms et al. 2017) and MP on the coasts of continental Chile and Easter Island (Hidalgo-Ruz and Thiel 2013), and on several European beaches (Lots et al. 2017).

The abundances found in the present study were consistent with other studies dealing with the MP contamination of sandy beaches (Table 1). Another recent study located along the English Channel revealed a concentration of $156 \pm 29 \mathrm{MP} \mathrm{kg}^{-1}$ d.w. and $143 \pm 13 \mathrm{MP} \mathrm{kg}^{-1}$ d.w. on two stations in Normandy (northwestern France) (Lots et al. 2017). The use of a single extraction step led to a potentially underestimated number of MP (Yu et al. 2016). However, due to the large variety of sampling and extraction techniques applied, comparison of reported MP concentrations between studies is difficult due to: (i) differences in the lower and upper size limit implemented, (ii) the sensitivity of the applied extraction technique, and (iii) differences in sampling techniques leading to a wide variety of reporting units (OSPAR 2017). Despite the different specifications for the three beaches, no significant differences in particle and fiber abundances were observed between these sites. Other authors have highlighted the same findings between their studied stations (Claessens et al. 2011; Dekiff et al. 2014; Lo et al. 2018).

\subsection{Impact of tide lines on the occurrence of particles and fibers}


The significance of sampling at several tidal heights was underlined by the European Union Technical Subgroup on Marine Litter (Galgani et al. 2013). The particle concentration on the beach of Boulogne-sur-Mer increased with the remoteness to the low tide line. This observation was consistent with a study conducted on the Belgian Coast, geographically close to the Côte d'Opale coastline (Van Cauwenberghe et al. 2013a). At Berck and Ambleteuse, no differences in particles and fibers concentrations were highlighted between tidal heights as observed by other authors. The abundance of MP was indeed identical between the upper and lower drift lines of three beaches of a German island (Dekiff et al. 2014). The shoreline and infralittoral zones from six beaches along the Slovenian coast exhibited the same MP content (Laglbauer et al. 2014). The impact of tidal height on total MP abundance was also insignificant among three Canadian beaches near Vancouver (Crichton et al. 2017), four beaches of the Baltic Sea Coast (Hengstmann et al. 2018), and ten beaches in Hong Kong (Lo et al. 2018). Overall, the present study and the literature demonstrate no clear trend in MP concentration related to tide lines.

\subsection{Possible origins of particles and fibers on the Côte d'Opale coastline}

The proportions of items observed in the present study could be linked to the possible MP origins, for example the water currents (Veerasingam et al. 2016). The trend towards a higher particle concentration at Boulogne-surMer could be related to the presence of a dike that lessens the currents and probably promotes particle accumulation in the beach sediments. Moreover, the current of the Pas-de-Calais coast is directed northward and constitutes the culmination of the general circulation from the Atlantic to the North Sea (Lazure and Desmare 2012). The currents could also carry MP from netting used in benthic dredges and trawls, which have the potential to contribute to MP (Lusher et al. 2017). Ropes could also contribute to MP loading when they were lost in the sea or subject to abrasion from benthic sediments (Lusher et al. 2017). These degradations could lead to some MP reaching the beach sediment under the influence of the currents and the swell. MP presence could also arise from plastic wastes on the beaches following their degradation by UV and the swell. However, the particle and fiber abundance in the present study (Table 1) could not be clearly related to one of these degradation processes. Black pellets (Figure S1) found in the present study at the high tide line at Boulogne-surMer could have been transported by these currents from other geographically close regions. Interestingly, these black pellets had already been observed along the English Channel from Normandy (France) to the Netherlands (Association SOS Mal de Seine 2011), but their origin is not yet understood.

In most studies, no differentiation is made between particle and fiber concentrations (Table 1). The high fiber proportion in the present study corroborated the global trend to a predominance of fibers as observed on beaches in Belgium (Claessens et al. 2011; Van Cauwenberghe et al. 2013a), France (Bosker et al. 2018), Germany 
(Dekiff et al. 2014; Hengstmann et al. 2018; Stolte et al. 2015), Iran (Naji et al. 2017), Mexico (Pinon-Colin et al. 2018), Poland (Graca et al. 2017), and the United States (Yu et al. 2018). Moreover, sewage treatment plants are present on the three studied sites (Ministère de la Transition écologique et solidaire 2016) and a large proportion of MP fibers found in the marine environment may be derived from sewage as a consequence of washing clothes (Browne et al. 2011; Henry et al. 2018). In addition, MP concentrations could be linked to human population densities, as suggested by Browne et al. (2011). Boulogne-sur-Mer has a population density three times higher than Berck and Ambleteuse, which have less than 2,000 inhabitants in winter (INSEE 2015). Despite these different numbers of inhabitants, particles and fibers abundance observed between the three sites was not different.

\subsection{Color considerations}

All sediment samples collected on the Côte d'Opale coastline contained colored particles and fibers. The observed panel of color strengthened the strong anthropogenic influx assumption of synthetic materials on these tourist beaches, as mentioned by a German study (Stolte et al. 2015). Blue fragments were already found in sediments on other beaches (Graca et al. 2017; Stolte et al. 2015). Five fiber colors were excluded from the count of the present study as they were also observed in the controls. This background contamination by fibers was already considered by other authors (Nuelle et al. 2014). Despite this exclusion of five colors, the results of the present study were consistent with the colors observed on two other French beaches where fibers were predominantly blue/black (78 to $92 \%$ ) and red (5 to $12 \%$ ) (Lots et al. 2017). The pink color observed in the present study could originate from red color degradation caused by biofilms or UV radiation (Browne et al. 2011).

\subsection{Particles identification}

MP identification using spectroscopic or thermal techniques remains an essential step in studies dealing with plastic pollution (Table 1). Among the analyzed particles, $68.8 \%$ were successfully identified by Py-GC/MS. The comparison of identification success rates between studies remained complicated as the number of analyzed MP and the identification methods were different. The rate of successful identification may be for example 57.5 $\%$ in a New Zealand study (Clunies-Ross et al. 2016) or $4.5 \%$ in a European study (Lots et al. 2017).

Black pellets from the high tide line at Boulogne-sur-Mer were made of PE/PP. They could correspond to black pellets observed in a previous study on the MP contamination of beaches along the French coastline (Association SOS Mal de Seine 2011). However, they were identified as PE using FTIR. The majority of the polymers identified in the present study have a low density $\left(<1 \mathrm{~g} . \mathrm{cm}^{-3}\right)$, which was already observed in beach sediment on 
the southern Baltic Sea (Graca et al. 2017) and corresponded to the extraction method of MP. The density of fully saturated salt solution $\left(1.2 \mathrm{~g} \mathrm{~cm}^{-3}\right)$ was indeed higher than the density of several polymers such as PP $(0.85$ $\left.0.92 \mathrm{~g} \mathrm{~cm}^{-3}\right)$, PE (0.89-0.98 $\left.\mathrm{g} \mathrm{cm}^{-3}\right)$, ABS $\left(1.03-1.21 \mathrm{~g} \mathrm{~cm}^{-3}\right)$ and PS $\left(0.01-1.06 \mathrm{~g} \mathrm{~cm}^{-3}\right)$ (Frias et al. 2018). Denser polymers like PET $\left(1.38-1.41 \mathrm{~g} \mathrm{~cm}^{-3}\right)$ and PVC $\left(1.38-1.41 \mathrm{~g} \mathrm{~cm}^{-3}\right)$ have not been extracted from sediment by flotation using this salt solution. Particles of PET and PVC were identified and corresponded to colored plastic particles (e.g. blue or red) collected and extracted visually before flotation treatment. PE was the main identified polymer at the three study sites along the Côte d'Opale coastline, which is not surprising as this is the main resin produced in Europe (PlasticsEurope 2017). These results provided preliminary characterization of MP found on three beaches located in the eastern area of the English Channel.

\section{Conclusion}

This student-based citizen science project provides initial data about MP abundance on the Côte d'Opale coastline located in Northern France. Particles and fibers concentration ranged from $23.4 \pm 18.9$ to $69.3 \pm 30.6$ items $\mathrm{kg}^{-1}$ d.w. No significant differences in overall particles and fibers abundances were highlighted between the three beaches despite their different hydrodynamic characteristics. However, an influence of tide lines was shown on particle abundance only at Boulogne-sur-Mer, probably due to the high proportion of black pellets at this tide line. The MP analysis by Py-GC/MS identified $68.8 \%$ of the analyzed particles, polyethylene being the major polymer. Other polymers include namely PP, PS, PET, PVC, PE/PP, ABS and rubber. Further investigations using citizen science would make it possible to diversify the sample locations to assess MP abundances and identification along the Côte d'Opale coastline or along the English Channel coastline, including samples along the Kent coast (United Kingdom). Moreover, the use of standardized protocols for collection and extraction of MP, as mentioned by Frias et al. (2018), could improve the understanding of MP pollution worldwide.

\section{Acknowledgments}

Ludovic Hermabessiere PhD was funded by the Hauts-de-France Region and ANSES (the French Agency for Food, Environmental and Occupational Health \& Safety). This work was funded by the French government and the Hauts-de-France Region in the framework of the CPER 2014-2020 MARCO project. We would like to thank Denis Watier who coordinates the professional projects within the University Institute of Technology. We also thank Margaux Danzero for her images and Marie Deblieck, Marie-Ange Huchin, Melinda Verite, and Florence Viudes for their technical support. 


\section{References}

Abidli S, Toumi H, Lahbib Y, Trigui El Menif N (2017) The First Evaluation of Microplastics in Sediments from the Complex Lagoon-Channel of Bizerte (Northern Tunisia) Water Air Soil Pollut 228 doi:10.1007/s11270-017-3439-9

Arthur C, Baker JE, Bamford HA (2009) Proceedings of the International Research Workshop on the Occurrence, Effects, and Fate of Microplastic Marine Debris, September 9-11, 2008, University of Washington Tacoma, Tacoma, WA, USA

Ashton K, Holmes L, Turner A (2010) Association of metals with plastic production pellets in the marine environment Mar Pollut Bull 60:2050-2055 doi:10.1016/j.marpolbul.2010.07.014

Association SOS Mal de Seine, Granulés plastiques industriels sur le littoral français (Manche-Mer du nord / Mer Celtique/ Golfe de Gascogne / Méditerranée) Rapport initial. (2011) http://maldeseine.free.fr/documents\%20granules/RAPPORT_version_WEB.htm. Accessed 07/11/2018

Bagaev A, Mizyuk A, Khatmullina L, Isachenko I, Chubarenko I (2017) Anthropogenic fibres in the Baltic Sea water column: Field data, laboratory and numerical testing of their motion Sci Total Environ 599600:560-571 doi:10.1016/j.scitotenv.2017.04.185

Bancin LJ, Walther BA, Lee YC, Kunz A (2019) Two-dimensional distribution and abundance of micro- and mesoplastic pollution in the surface sediment of Xialiao Beach, New Taipei City, Taiwan Mar Pollut Bull 140:75-85 doi:10.1016/j.marpolbul.2019.01.028

Barrows APW, Christiansen KS, Bode ET, Hoellein TJ (2018) A watershed-scale, citizen science approach to quantifying microplastic concentration in a mixed land-use river Water Res 147:382-392 doi:10.1016/j.watres.2018.10.013

Besley A, Vijver MG, Behrens P, Bosker T (2017) A standardized method for sampling and extraction methods for quantifying microplastics in beach sand Mar Pollut Bull 114:77-83 doi:10.1016/j.marpolbul.2016.08.055

Bosker T, Guaita L, Behrens P (2018) Microplastic pollution on Caribbean beaches in the Lesser Antilles Mar Pollut Bull 133:442-447 doi:10.1016/j.marpolbul.2018.05.060

Browne M, A, Galloway T, S, Thompson R, C (2010) Spatial Patterns of Plastic Debris along Estuarine Shorelines Environ Sci Technol 44:3404-3409

Browne MA, Crump P, Niven SJ, Teuten E, Tonkin A, Galloway T, Thompson R (2011) Accumulation of microplastic on shorelines woldwide: sources and sinks Environ Sci Technol 45:9175-9179 doi:10.1021/es201811s

Browne MA, Galloway T, Thompson R (2007) Microplastic — an emerging contaminant of potential concern? Integr Environ Assess Manag 3:559-561

Carpenter EJ, Anderson SJ, Harvey GR, Miklas HP, Peck BB (1972) Polystyrene spherules in coastal waters Science 178:749-750

Chubarenko I, Bagaev A, Zobkov M, Esiukova E (2016) On some physical and dynamical properties of microplastic particles in marine environment Mar Pollut Bull 108:105-112 doi:10.1016/j.marpolbul.2016.04.048

Chubarenko IP, Esiukova EE, Bagaev AV, Bagaeva MA, Grave AN (2018) Three-dimensional distribution of anthropogenic microparticles in the body of sandy beaches Sci Total Environ 628-629:1340-1351 doi:10.1016/j.scitotenv.2018.02.167

Claessens M, De Meester S, Van Landuyt L, De Clerck K, Janssen CR (2011) Occurrence and distribution of microplastics in marine sediments along the Belgian coast Mar Pollut Bull 62:2199-2204 doi:10.1016/j.marpolbul.2011.06.030

Clunies-Ross PJ, Smith GPS, Gordon KC, Gaw S (2016) Synthetic shorelines in New Zealand? Quantification and characterisation of microplastic pollution on Canterbury's coastlines N Z J Mar Freshwater Res 50:317-325 doi:10.1080/00288330.2015.1132747

Collicutt B, Juanes F, Dudas SE (2019) Microplastics in juvenile Chinook salmon and their nearshore environments on the east coast of Vancouver Island Environ Pollut 244:135-142 doi:10.1016/j.envpol.2018.09.137

Constant M, Kerhervé P, Mino-Vercellio-Verollet M, Dumontier M, Sànchez Vidal A, Canals M, Heussner S (2019) Beached microplastics in the Northwestern Mediterranean Sea Marine Pollution Bulletin 142:263-273 doi:10.1016/j.marpolbul.2019.03.032

Crichton EM, Noël M, Gies EA, Ross PS (2017) A novel, density-independent and FTIR-compatible approach for the rapid extraction of microplastics from aquatic sediments Anal Methods 9:1419-1428 doi:10.1039/c6ay02733d

De Mendiburu F (2017) Agricolae: Statistical Procedures for Agricultural Research. R package version 1.2-7.

Dehaut A et al. (2016) Microplastics in seafood: Benchmark protocol for their extraction and characterization Environ Pollut 215:223-233 doi:10.1016/j.envpol.2016.05.018 
Dekiff JH, Remy D, Klasmeier J, Fries E (2014) Occurrence and spatial distribution of microplastics in sediments from Norderney Environ Pollut 186:248-256 doi:10.1016/j.envpol.2013.11.019

Dickinson JL et al. (2012) The current state of citizen science as a tool for ecological research and public engagement Front Ecol Environ 10:291-297 doi:10.1890/110236

Endo S, Yuyama M, Takada H (2013) Desorption kinetics of hydrophobic organic contaminants from marine plastic pellets Mar Pollut Bull 74:125-131 doi:10.1016/j.marpolbul.2013.07.018

Esiukova E (2017) Plastic pollution on the Baltic beaches of Kaliningrad region, Russia Mar Pollut Bull 114:1072-1080 doi:10.1016/j.marpolbul.2016.10.001

Frias J, Nash R, Pagter E, O'Connor I (2018) Standardised protocol formonitoring MPs in sediments. doi:10.13140/RG.2.2.36256.89601/1

Galgani F et al. (2013) Guidance on Monitoring Marine Litter in European Seas, Publication Office of the European Union, Luxembourg edn. European Commission. doi:10.2788/99475

Graca B, Szewc K, Zakrzewska D, Dolega A, Szczerbowska-Boruchowska M (2017) Sources and fate of microplastics in marine and beach sediments of the Southern Baltic Sea-a preliminary study Environ Sci Pollut Res Int 24:7650-7661 doi:10.1007/s11356-017-8419-5

Hengstmann E, Tamminga M, Vom Bruch C, Fischer EK (2018) Microplastic in beach sediments of the Isle of Rugen (Baltic Sea) - Implementing a novel glass elutriation column Mar Pollut Bull 126:263-274 doi:10.1016/j.marpolbul.2017.11.010

Henry B, Laitala K, Klepp IG (2018) Microfibres from apparel and home textiles: Prospects for including microplastics in environmental sustainability assessment Sci Total Environ 652:483-494 doi:10.1016/j.scitotenv.2018.10.166

Hidalgo-Ruz V, Thiel M (2013) Distribution and abundance of small plastic debris on beaches in the SE Pacific (Chile): a study supported by a citizen science project Mar Environ Res 87-88:12-18 doi:10.1016/j.marenvres.2013.02.015

Hidalgo-Ruz V, Thiel M (2015) The Contribution of Citizen Scientists to the Monitoring of Marine Litter. In: Marine Anthropogenic Litter. pp 429-447. doi:10.1007/978-3-319-16510-3_16

Holmes LA, Turner A, Thompson RC (2012) Adsorption of trace metals to plastic resin pellets in the marine environment Environ Pollut 160:42-48 doi:10.1016/j.envpol.2011.08.052

Hopewell J, Dvorak R, Kosior E (2009) Plastics recycling: challenges and opportunities Philos Trans R Soc Lond B Biol Sci 364:2115-2126

INSEE, Institut national de la statistique et des études économiques (2015) https://www.insee.fr/fr/accueil. Accessed 06/29/2018

Inventaire National du Patrimoine Naturel (INPN) (2018) https://inpn.mnhn.fr/collTerr/commune/80333/tab/espaces. Accessed 06/29/2018

Kedzierski M, Le Tilly V, Bourseau P, Bellegou H, Cesar G, Sire O, Bruzaud S (2016) Microplastics elutriation from sandy sediments: A granulometric approach Mar Pollut Bull 107:315-323 doi:10.1016/j.marpolbul.2016.03.041

Kooi M, Nes EHV, Scheffer M, Koelmans AA (2017) Ups and Downs in the Ocean: Effects of Biofouling on Vertical Transport of Microplastics Environ Sci Technol 51:7963-7971 doi:10.1021/acs.est.6b04702

Korez S̆, Gutow L, Saborowski R (2019) Microplastics at the strandlines of Slovenian beaches Marine Pollution Bulletin 145:334-342 doi:10.1016/j.marpolbul.2019.05.054

Laglbauer BJL et al. (2014) Macrodebris and microplastics from beaches in Slovenia Mar Pollut Bull 89:356366 doi:10.1016/j.marpolbul.2014.09.036

Lazure P., Desmare S., Caractéristiques et état écologique Manche - Mer du Nord, Etat physique et chimique, caractéristiques physiques, Courantologie (2012)

https://www.ifremer.fr/sextant_doc/dcsmm/documents/Evaluation_initiale/MMN/EE/MMN_EE_06_Co urantologie.pdf. Accessed 01/15/2019

Li J, Zhang H, Zhang K, Yang R, Li R, Li Y (2018) Characterization, source, and retention of microplastic in sandy beaches and mangrove wetlands of the Qinzhou Bay, China Mar Pollut Bull 136:401-406 doi:10.1016/j.marpolbul.2018.09.025

Liboiron M et al. (2016) Low plastic ingestion rate in Atlantic cod (Gadus morhua) from Newfoundland destined for human consumption collected through citizen science methods Mar Pollut Bull 113:428437 doi:10.1016/j.marpolbul.2016.10.043

Liebezeit G, Dubaish F (2012) Microplastics in beaches of the East Frisian islands Spiekeroog and Kachelotplate Bull Environ Contam Toxicol 89:213-217 doi:10.1007/s00128-012-0642-7

Lo HS, Xu X, Wong CY, Cheung SG (2018) Comparisons of microplastic pollution between mudflats and sandy beaches in Hong Kong Environ Pollut 236:208-217 doi:10.1016/j.envpol.2018.01.031

Lots FAE, Behrens P, Vijver MG, Horton AA, Bosker T (2017) A large-scale investigation of microplastic contamination: Abundance and characteristics of microplastics in European beach sediment Mar Pollut Bull 123:219-226 doi:10.1016/j.marpolbul.2017.08.057 
Lusher A (2015) Microplastics in the marine environment: distribution, interactions and effects. In: Bergmann, M, Gutow, L, Klages, M (Eds), Marine anthropogenic litter Springer, Berlin:245-307

Lusher AL, Hollman PCH, Mendoza-Hill JJ (2017) Microplastics in fisheries and aquaculture: status of knowledge on their occurrence and implications for aquatic organisms and food safety. vol 615. Rome, Italy

Ministère de l'écologie, du développement durable et de l'énergie, données hydrologiques de synthèse (1963 2018), E5505720 L'Authie à Dompierre-sur-Authie (2018a) http://www.hydro.eaufrance.fr/stations/E5505720\&procedure=synthese. Accessed 06/29/2018

Ministère de l'écologie, du développement durable et de l'énergie, données hydrologiques de synthèse (1965 1991), E5310210 La Liane à Hesdigneul-lès-Boulogne (2018b) http://www.hydro.eaufrance.fr/stations/E5310210\&procedure=synthese. Accessed 06/29/2018

Ministère de l'écologie, du développement durable et de l'énergie, données hydrologiques de synthèse (1980 2018), E5105710 La Slack à Rinxent (2018c) http://www.hydro.eaufrance.fr/stations/E5105710\&procedure=synthese. Accessed 06/29/2018

Ministère de la Transition écologique et solidaire, Portail d'information sur l'assainissement communal (2016) http://assainissement.developpement-durable.gouv.fr/. Accessed 06/29/2018

Naji A, Esmaili Z, Khan FR (2017) Plastic debris and microplastics along the beaches of the Strait of Hormuz, Persian Gulf Mar Pollut Bull 114:1057-1062 doi:10.1016/j.marpolbul.2016.11.032

Nelms SE, Coombes C, Foster LC, Galloway TS, Godley BJ, Lindeque PK, Witt MJ (2017) Marine anthropogenic litter on British beaches: A 10-year nationwide assessment using citizen science data Sci Total Environ 579:1399-1409 doi:10.1016/j.scitotenv.2016.11.137

Ng KL, Obbard JP (2006) Prevalence of microplastics in Singapore's coastal marine environment Mar Pollut Bull 52:761-767 doi:10.1016/j.marpolbul.2005.11.017

Nuelle MT, Dekiff JH, Remy D, Fries E (2014) A new analytical approach for monitoring microplastics in marine sediments Environ Pollut 184:161-169 doi:10.1016/j.envpol.2013.07.027

Ogata Y et al. (2009) International Pellet Watch: global monitoring of persistent organic pollutants (POPs) in coastal waters. 1. Initial phase data on PCBs, DDTs, and HCHs Mar Pollut Bull 58:1437-1446 doi:10.1016/j.marpolbul.2009.06.014

OSPAR (2017) Assessment document of land-based inputs of microplastics in the marine environment.

Pinon-Colin TJ, Rodriguez-Jimenez R, Pastrana-Corral MA, Rogel-Hernandez E, Wakida FT (2018) Microplastics on sandy beaches of the Baja California Peninsula, Mexico Mar Pollut Bull 131:63-71 doi:10.1016/j.marpolbul.2018.03.055

Piperagkas O, Papageorgiou N, Karakassis I (2019) Qualitative and quantitative assessment of microplastics in three sandy Mediterranean beaches, including different methodological approaches Estuarine, Coastal and Shelf Science 219:169-175 doi:10.1016/j.ecss.2019.02.016

PlasticsEurope, Plastics - the Facts 2017: An analysis of European plastics production, demand and waste data. (2017) https://www.plasticseurope.org/application/files/1715/2111/1527/Plastics the facts 2017_FINAL for website.pdf. Accessed 06/29/2018

Qiu Q, Peng J, Yu X, Chen F, Wang J, Dong F (2015) Occurrence of microplastics in the coastal marine environment: First observation on sediment of China Mar Pollut Bull 98:274-280 doi:10.1016/j.marpolbul.2015.07.028

R Core Team (2017) R: A language and environment for statistical computing. Vienna, Austria; 2016.

Retama I, Jonathan MP, Shruti VC, Velumani S, Sarkar SK, Roy PD, Rodriguez-Espinosa PF (2016) Microplastics in tourist beaches of Huatulco Bay, Pacific coast of southern Mexico Mar Pollut Bull 113:530-535 doi:10.1016/j.marpolbul.2016.08.053

Sagawa N, Kawaai K, Hinata H (2018) Abundance and size of microplastics in a coastal sea: Comparison among bottom sediment, beach sediment, and surface water Mar Pollut Bull 133:532-542 doi:10.1016/j.marpolbul.2018.05.036

Sathish N, Jeyasanta KI, Patterson J (2019) Abundance, characteristics and surface degradation features of microplastics in beach sediments of five coastal areas in Tamil Nadu, India Marine Pollution Bulletin 142:112-118 doi:10.1016/j.marpolbul.2019.03.037

Service Sandre Eau de France, Fiche cours d'eau La Liane (E53-0020) (2012a) http://services.sandre.eaufrance.fr/Courdo/Fiche/client/fiche courdo.php?CdSandre=E53-0020. Accessed 06/29/2018

Service Sandre Eau de France, Fiche cours d'eau Slack E5100570 (2012b) http://services.sandre.eaufrance.fr/Courdo/Fiche/client/fiche courdo.php?CdSandre=E5100570. Accessed 06/29/2018 
Service Sandre Eau de France, Fiche cours d'eau, Authie (E5500570) (2012c) http://services.sandre.eaufrance.fr/Courdo/Fiche/client/fiche courdo.php?CdSandre=E5500570. Accessed 06/29/2018

Stolte A, Forster S, Gerdts G, Schubert H (2015) Microplastic concentrations in beach sediments along the German Baltic coast Mar Pollut Bull 99:216-229 doi:10.1016/j.marpolbul.2015.07.022

Thompson RC et al. (2004) Lost at sea: where is all the plastic? Science 304:838-838

Tsuge S, Ohtani H, Watanabe C (2011) Pyrolysis-GC/MS data book of synthetic polymers: pyrograms, thermograms and MS of pyrolyzates. Elsevier,p.390,

Van Cauwenberghe L, Claessens M, Vandegehuchte MB, Mees J, Janssen CR (2013a) Assessment of marine debris on the Belgian Continental Shelf Mar Pollut Bull 73:161-169 doi:10.1016/j.marpolbul.2013.05.026

Van Cauwenberghe L, Devriese L, Galgani F, Robbens J, Janssen CR (2015) Microplastics in sediments: A review of techniques, occurrence and effects Mar Environ Res 111:5-17 doi:10.1016/j.marenvres.2015.06.007

Van Cauwenberghe L, Vanreusel A, Mees J, Janssen CR (2013b) Microplastic pollution in deep-sea sediments Environ Pollut 182:495-499 doi:10.1016/j.envpol.2013.08.013

Veerasingam S, Mugilarasan M, Venkatachalapathy R, Vethamony P (2016) Influence of 2015 flood on the distribution and occurrence of microplastic pellets along the Chennai coast, India Mar Pollut Bull 109:196-204 doi:10.1016/j.marpolbul.2016.05.082

Vérin, F.,Devreker, D.,Lefebvre, A., Etude sanitaire de la zone 62.06 "Audresselles Ambleteuse" (2018) Ifremer, Direction Océanographie et Dynamique des Écosystèmes Laboratoire Environnement littoral et Ressources aquacoles Boulogne-sur-Mer. http://archimer.ifremer.fr/doc/00440/55138/56614.pdf. Accessed 06/29/2018

Whitmire S.L, Van Bloem S.J., Quantification of microplastics on National Park Beaches (2017) National Park Service. http://npshistory.com/publications/water/microplastics.pdf. Accessed 01/15/2019

Yabanlı M, Yozukmaz A, Şener İ, Ölmez ÖT (2019) Microplastic pollution at the intersection of the Aegean and Mediterranean Seas: A study of the Datça Peninsula (Turkey) Marine Pollution Bulletin 145:47-55 doi:10.1016/j.marpolbul.2019.05.003

Yu X, Ladewig S, Bao S, Toline CA, Whitmire S, Chow AT (2018) Occurrence and distribution of microplastics at selected coastal sites along the southeastern United States Sci Total Environ 613-614:298-305 doi:10.1016/j.scitotenv.2017.09.100

Yu X, Peng J, Wang J, Wang K, Bao S (2016) Occurrence of microplastics in the beach sand of the Chinese inner sea: the Bohai Sea Environ Pollut 214:722-730 doi:10.1016/j.envpol.2016.04.080 
Table 1: Overview of microplastics studies in beach sediments, where expression of abundance is on a dry weight basis (i.e. items $\mathrm{kg}^{-1}$ d.w.) (NC is noted when abundances were not communicated)

Figure 1: Location map showing the geographical position of the Côte d'Opale coastline within France (A) and the position of the three sampling sites, namely: Ambleteuse (B); Boulogne-sur-Mer (C); Berck (D). The samples were collected at three different tide lines: HTL $=$ high tide line; IZ = middle of the intertidal zone; $\mathrm{LTL}=$ low tide line.

Figure 2: Average number of particles (in white), fibers (in grey) and particles + fibers (in black) expressed as $\mathrm{kg}^{-1}$ d.w. for each station. Bars represents the standard deviation for each station $(\mathrm{n}=9)$.

Figure 3: Mean number of particles (A) and fibers (B) $\mathrm{kg}^{-1}$ d.w. at each tide line from the three stations. Bars represents the standard deviation from $n=3$ for each sampling. Bars with different letters are statistically different $(p<0.05)$.

Figure 4: Proportion of particles (A) and fibers (B) per color at each station.

Figure 5: Relative abundance (\%) of identified polymers. 
Table 1: Overview of microplastics studies in beach sediments, where expression of abundance is on a dry weight basis (i.e. items $\mathrm{kg}^{-1} \mathrm{~d}$.w.) ( $\mathrm{NC}$ is noted when abundances were not communicated).

\begin{tabular}{|c|c|c|c|c|c|c|c|c|c|}
\hline & \multirow{2}{*}{ Country } & \multirow{2}{*}{ Location } & & \multicolumn{3}{|c|}{ Abundance (items kg ${ }^{-1}$ d.w) } & \multirow{2}{*}{ Size $(\mathrm{mm})$} & \multirow{2}{*}{ Method of identification } & \multirow{2}{*}{ Reference } \\
\hline & & & & particles & fibers & Total & & & \\
\hline \multirow{20}{*}{ 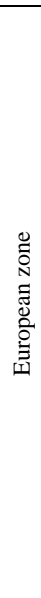 } & France & Ambleteuse & mean \pm SD & $2.5 \pm 3.8$ & $31.4 \pm 21.7$ & $33.9 \pm 24.9$ & $<5$ & Py-GC/MS & This study \\
\hline & & & $\min -\max$ & $0-9.5$ & $4.36-62.98$ & $4.36-71.38$ & & & \\
\hline & & Boulogne-sur-Mer & mean \pm SD & $9 \pm 13.1$ & $37.5 \pm 15.5$ & $46.5 \pm 17.3$ & & & \\
\hline & & & $\min -\max$ & $0-39.55$ & $13.54-62.11$ & $16.10-65.35$ & & & \\
\hline & & Berck & mean $\pm \mathrm{SD}$ & $3.5 \pm 5.3$ & $44.6 \pm 41$ & $48.1 \pm 40.9$ & & & \\
\hline & & & $\min -\max$ & $0-16.86$ & $6.78-120.03$ & $6.78-122.12$ & & & \\
\hline & Belgium & 3 beaches along the Belgian coast & mean \pm SEM & $6.3 \pm 2.5$ & $81 \pm 37.2$ & $92.8 \pm 37.2$ & $0.038-1$ & FTIR & Claessens et al. (2011) \\
\hline & Belgium & 4 beaches along the Belgian coast & mean $\pm \mathrm{SD}$ & $\mathrm{NC}$ & $\mathrm{NC}$ & $13 \pm 9$ & $<1$ & none & Van Cauwenberghe et al. (2013a) \\
\hline & Several countries & 23 beaches across 13 countries & range of mean \pm SEM & $\mathrm{NC}$ & $\mathrm{NC}$ & $72 \pm 24-1512 \pm 187$ & $0.3-5$ & Raman & Lots et al. (2017) \\
\hline & France & 2 sites of the western Gulf of Lion & range of mean $\pm \mathrm{SD}$ & $\mathrm{NC}$ & $\mathrm{NC}$ & $58 \pm 53-166 \pm 205$ & $0.063-5$ & FTIR & Constant et al. (2019) \\
\hline & Frisian Island & 2 transects in Kachelotplate \&Spiekeroog islands & $\min -\max$ & $0-62,100^{\mathrm{a}}$ & $100-1,400^{\mathrm{a}}$ & $\mathrm{NC}$ & $<5$ & none & Liebezeit and Dubaish (2012) \\
\hline & Germany & One beach of an eastern Frisian island & $\min -\max$ & NC & $\mathrm{NC}$ & $1-2$ & $<1$ & Py-GC/MS & Nuelle et al. (2014) \\
\hline & Germany & 3 beaches of Norderney island & $\min -\max$ & NC & $\mathrm{NC}$ & $1,3-2,3$ & $<1$ & TD-Py-GC/MS & Dekiff et al. (2014) \\
\hline & Germany & 4 beaches of the Rostock area & $\min -\max$ & $0-4$ & $42-532$ & $\mathrm{NC}$ & $0.055-1$ & none & Stolte et al. (2015) \\
\hline & Germany & 4 beaches of the Baltic Sea Coast & median & 22.96 & 54.37 & 88.1 & $0.063-5$ & none & Hengstmann et al. (2018) \\
\hline & Greece & 3 beaches in northern Crete & Range of number and of mean $\pm \mathrm{SD}$ & $0-64.2$ & $2.5-22.3$ & $5 \pm 5-85 \pm 141$ & $<5$ & FTIR & Piperagkas et al. (2019) \\
\hline & Poland & 2 beaches of the Gulf of Gdansk & mean \pm SD & $\mathrm{NC}$ & $\mathrm{NC}$ & $39 \pm 10$ & $\leq 5$ & Micro-FTIR & Graca et al. (2017) \\
\hline & Slovenia & 6 beaches along the Slovenian coast & median & $\mathrm{NC}$ & $\mathrm{NC}$ & 133.3 & $0.25-5$ & none & Laglbauer et al. (2014) \\
\hline & & 9 beaches along the Slovenian coast in march & range of mean $\pm \mathrm{SD}$ & $\mathrm{NC}$ & $\mathrm{NC}$ & $0.5 \pm 0.5-1 \pm 0.8$ & & ATR-FTIR & Korez et al. (2019) \\
\hline & The Netherlands & Meijendel beach & $\min -\max$ & $\mathrm{NC}$ & $\mathrm{NC}$ & $200-1500$ & $<5$ & none & Besley et al. (2017) \\
\hline \multirow{19}{*}{ 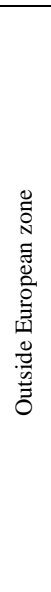 } & Canada & 4 beaches of Vancouver Island & mean \pm SD & $\mathrm{NC}$ & $\mathrm{NC}$ & $60.2 \pm 63.4$ & $0.1-5$ & none & Collicutt et al. (2019) \\
\hline & China & 5 beaches along the South Sea coast & $\min -\max$ & $\mathrm{NC}$ & $\mathrm{NC}$ & $5020-8720$ & $<5$ & Micro-FTIR & Qiu et al. (2015) \\
\hline & China & 3 beaches in the north of the Bohai Sea & $\min -\max$ & $\mathrm{NC}$ & $\mathrm{NC}$ & $102.9-163.3$ & $0.01-5$ & FTIR & Yu et al. (2016) \\
\hline & China & 4 beaches in the Qinzhou Bay & mean \pm SD & $\mathrm{NC}$ & $\mathrm{NC}$ & $3266 \pm 6390.8$ & $<5$ & FTIR & Li et al. (2018) \\
\hline & India & 5 beaches along the coast of Tamil Nadu & range of mean $\pm \mathrm{SD}$ & $\mathrm{NC}$ & $\mathrm{NC}$ & $33 \pm 30-439 \pm 172$ & & FTIR & Sathish et al. (2019) \\
\hline & Iran & 5 beaches along the Strait of Hormuz in the Persian Gulf & range of mean $\pm \mathrm{SD}$ & $\mathrm{NC}$ & $\mathrm{NC}$ & $2 \pm 1-1258 \pm 291$ & $<4.75$ & FTIR & Naji et al. (2017) \\
\hline & Japan & 6 beaches of Hiroshima Bay & $\min -\max$ & $\mathrm{NC}$ & $\mathrm{NC}$ & $5-1245$ & $0.3-5$ & FE-SEM and X-ray & Sagawa et al. (2018) \\
\hline & Lesser Antilles & 21 beaches over four volcanic islands & mean \pm SEM & $\mathrm{NC}$ & $\mathrm{NC}$ & $261 \pm 6$ & $0.3-5$ & none & Bosker et al. (2018) \\
\hline & Mexico & 9 beaches in Huatculco bay & $\min -\max$ & $\mathrm{NC}$ & $0-2300^{\mathrm{b}}$ & $\mathrm{NC}$ & $<5$ & none & Retama et al. (2016) \\
\hline & Mexico & 21 beaches of the Baja California Peninsula & mean $\pm \mathrm{SD}$ & $\mathrm{NC}$ & $\mathrm{NC}$ & $135 \pm 92$ & $<5$ & FTIR & Pinon-Colin et al. (2018) \\
\hline & New Zealand & 5 beaches in the Canterbury region & mean $\pm \mathrm{SD}$ & NC & NC & $21.2 \pm 16.5$ & $<5$ & Micro-Raman spectroscopy & Clunies-Ross et al. (2016) \\
\hline & Russia & 13 beaches in the Kaliningrad region & $\min -\max$ & $\mathrm{NC}$ & $\mathrm{NC}$ & $1.3-36.3$ & $0.5-5$ & none & Esiukova (2017) \\
\hline & Russia & $\begin{array}{l}3 \text { beaches of the south-eastern part of the Baltic sea (6) } \\
\text { sampling at wrack lines) }\end{array}$ & $\min -\max$ & $31-365$ & $5-335$ & $53-572$ & $0.5-5$ & none & Chubarenko et al. (2018) \\
\hline & Singapore & 5 beaches Singapore's coastline & $\min -\max$ & $\mathrm{NC}$ & $\mathrm{NC}$ & $2-8$ & $0.0016-5$ & IR spectroscopy & Ng and Obbard (2006) \\
\hline & Taiwan & Xialiao Beach & mean & $\mathrm{NC}$ & $\mathrm{NC}$ & 17.7 & $1-5$ & FTIR or Raman & Bancin et al. (2019) \\
\hline & Tunisia & 4 beaches in the lagoon of Bizerte & $\min -\max$ & $\mathrm{NC}$ & $\mathrm{NC}$ & $3000-18000$ & $0.3-5$ & none & Abidli et al. (2017) \\
\hline & Turkey & 4 beaches in the Datça Peninsula & mean $\pm \mathrm{SD}$ & $3313 \pm 545$ & $585 \pm 110$ & $1154.4 \pm 700.3$ & $<5$ & ATR-FTIR & Yabanlı et al. (2019) \\
\hline & United States & 37 beaches in national parks & range of mean \pm SEM & NC & $\mathrm{NC}$ & $21 \pm 4.3-221.3 \pm 28.8$ & $<2$ & none & Whitmire and Bloem (2017) \\
\hline & United States & 18 national park beaches in the Southeastern US & $\min -\max$ & $\mathrm{NC}$ & $\mathrm{NC}$ & $43-443$ & $0.01-5$ & FTIR & Yu et al. (2018) \\
\hline
\end{tabular}

SD : Standard Deviation; SEM: Standard Error of the Mean; Py-GC/MS: pyrolysis-gas chromatography-mass spectrometry; TD-Py-GC/MS: therr
field emission scanning electron microscopy; SEM-EDS: scanning electron microscopy (SEM) with energy-dispersive-X-ray spectroscopy (EDS) 

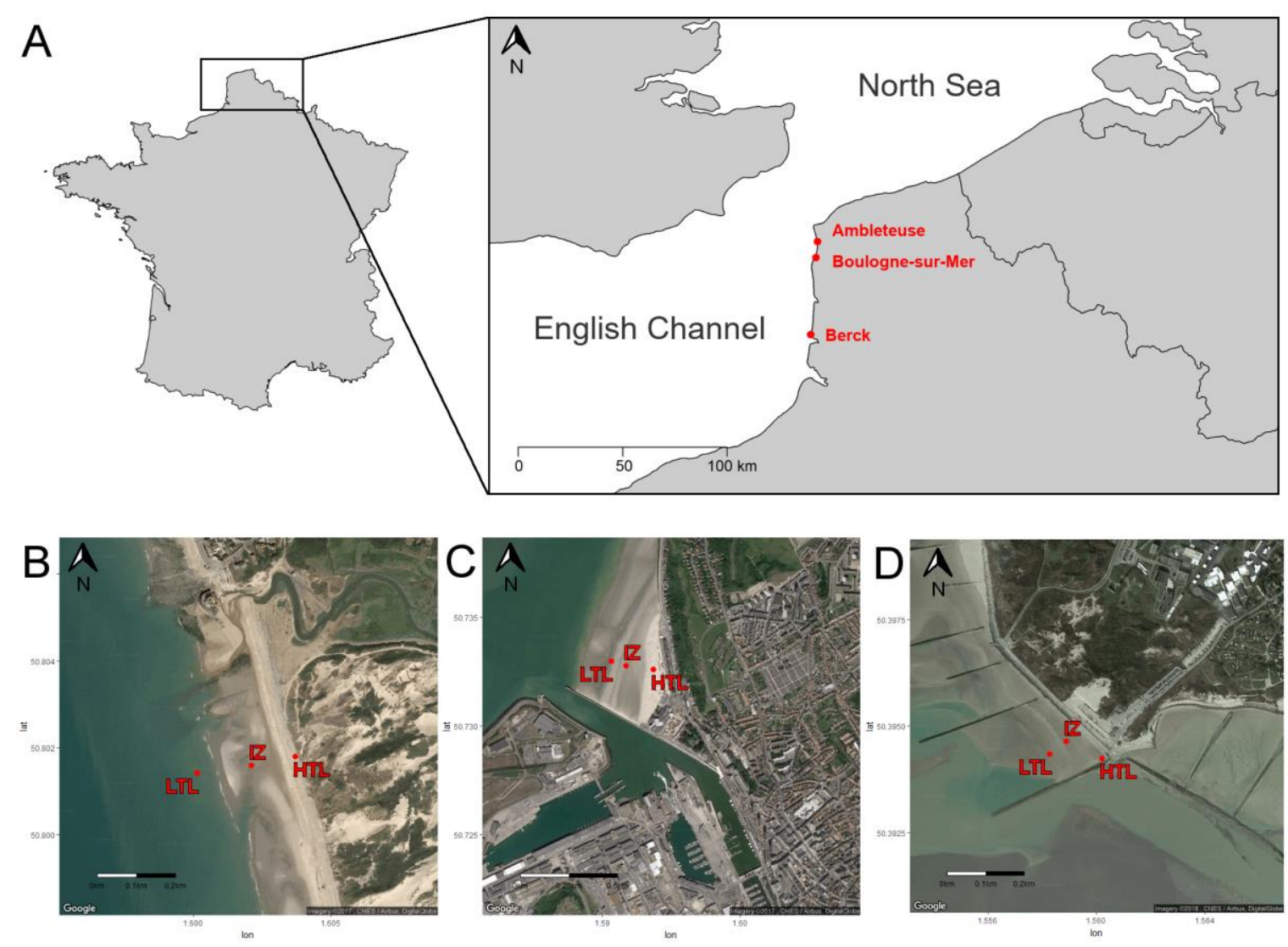

Figure 1: Location map showing the geographical position of the Côte d'Opale coastline within France (A) and the position of the three sampling sites, namely: Ambleteuse (B); Boulogne-sur-Mer (C); Berck (D). The samples were collected at three different tide lines: HTL = high tide line; $\mathrm{IZ}=$ middle of the intertidal zone; LTL $=$ low tide line. 


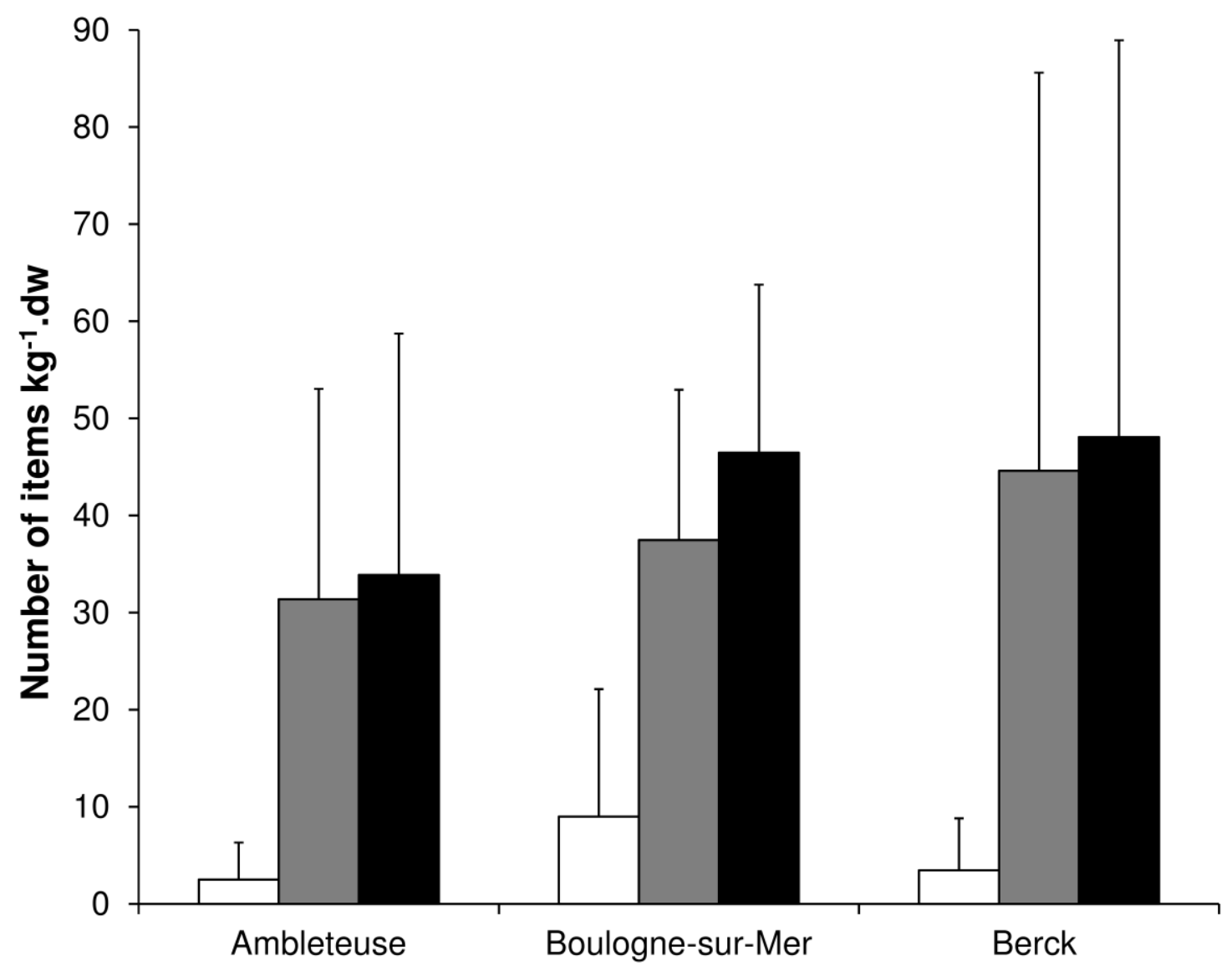

Figure 2: Average number of particles (in white), fibers (in grey) and particles + fibers (in black) expressed as $\mathrm{kg}^{-1}$ d.w. for each station. Bars represents the standard deviation for each station $(\mathrm{n}=9)$ 
A

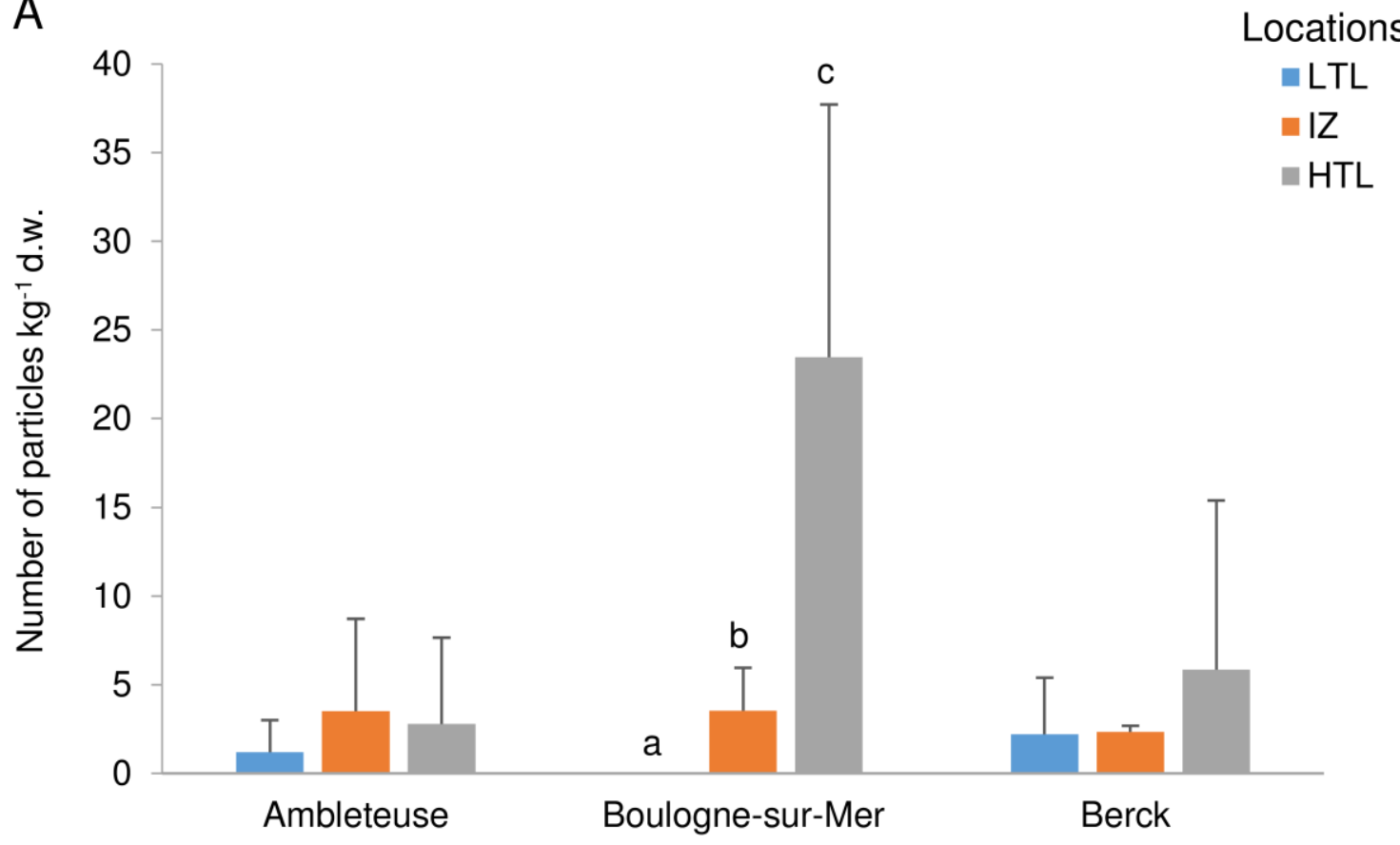

B

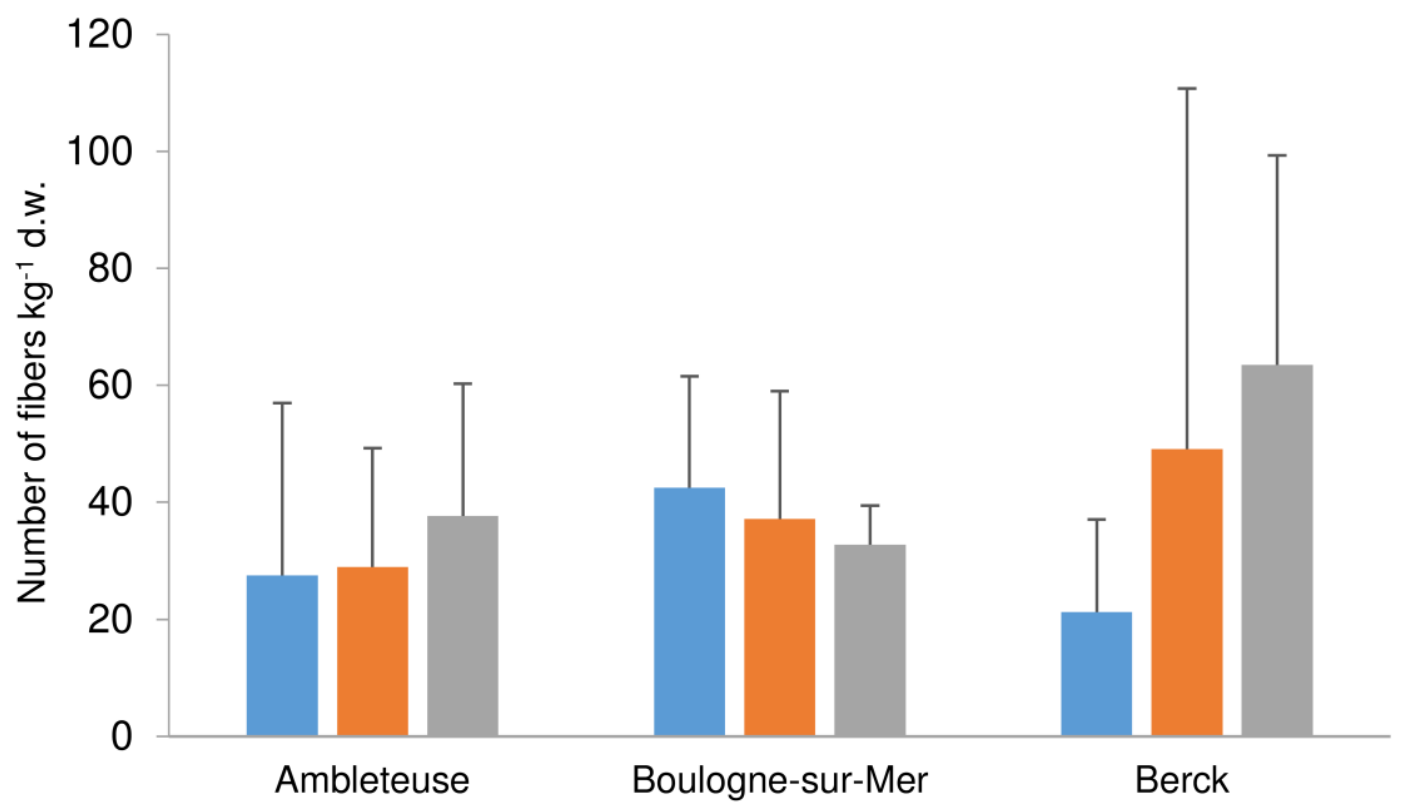

Figure 3: Average number of particles (A) and fibers (B) $\mathrm{kg}^{-1} \mathrm{~d} . \mathrm{w}$. at each tide line from the three stations. Bars represents the standard deviation from $n=3$ for each sampling. Bars with different letters are statistically different $(p<0.05)$. 
A

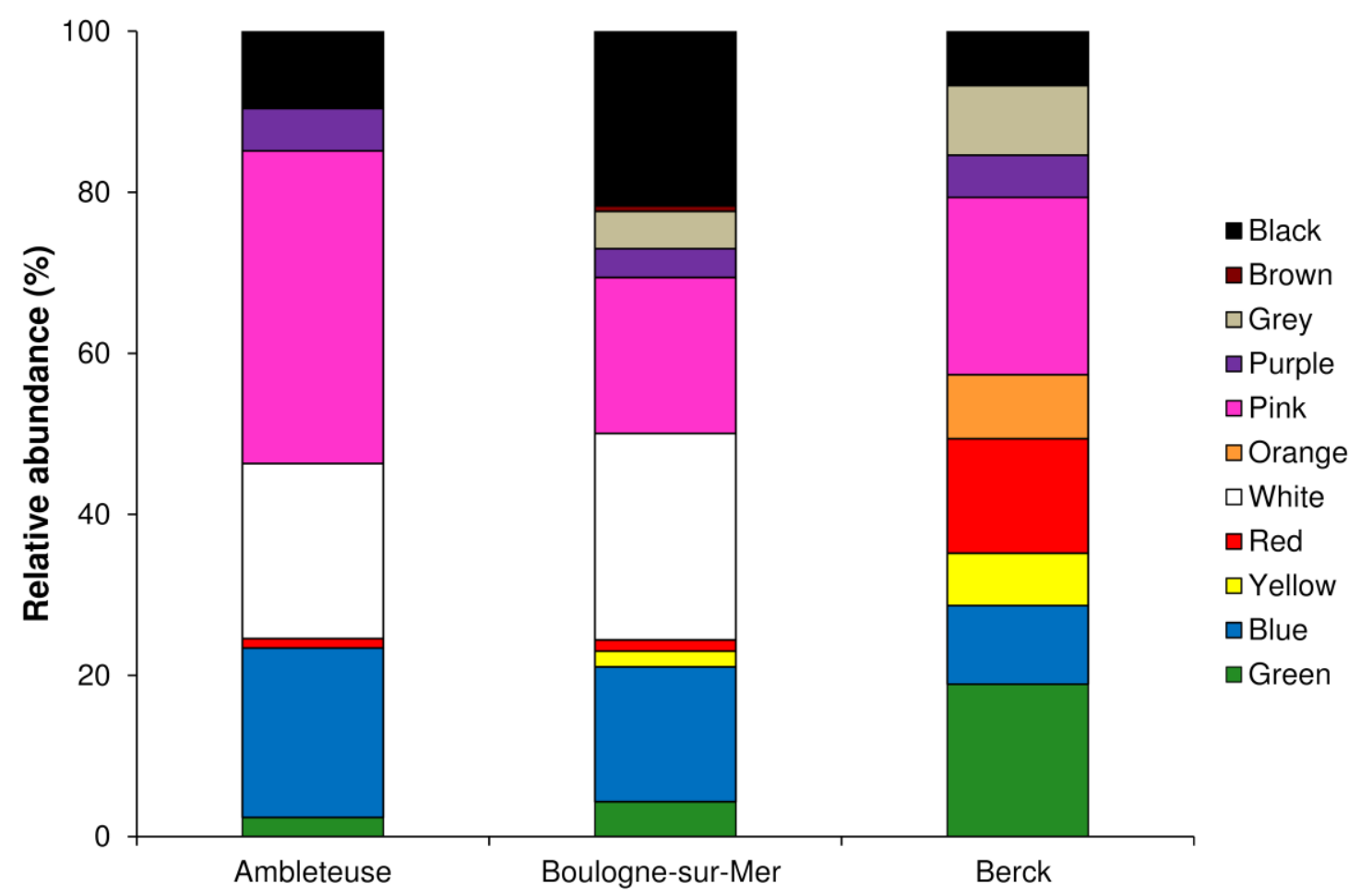

B

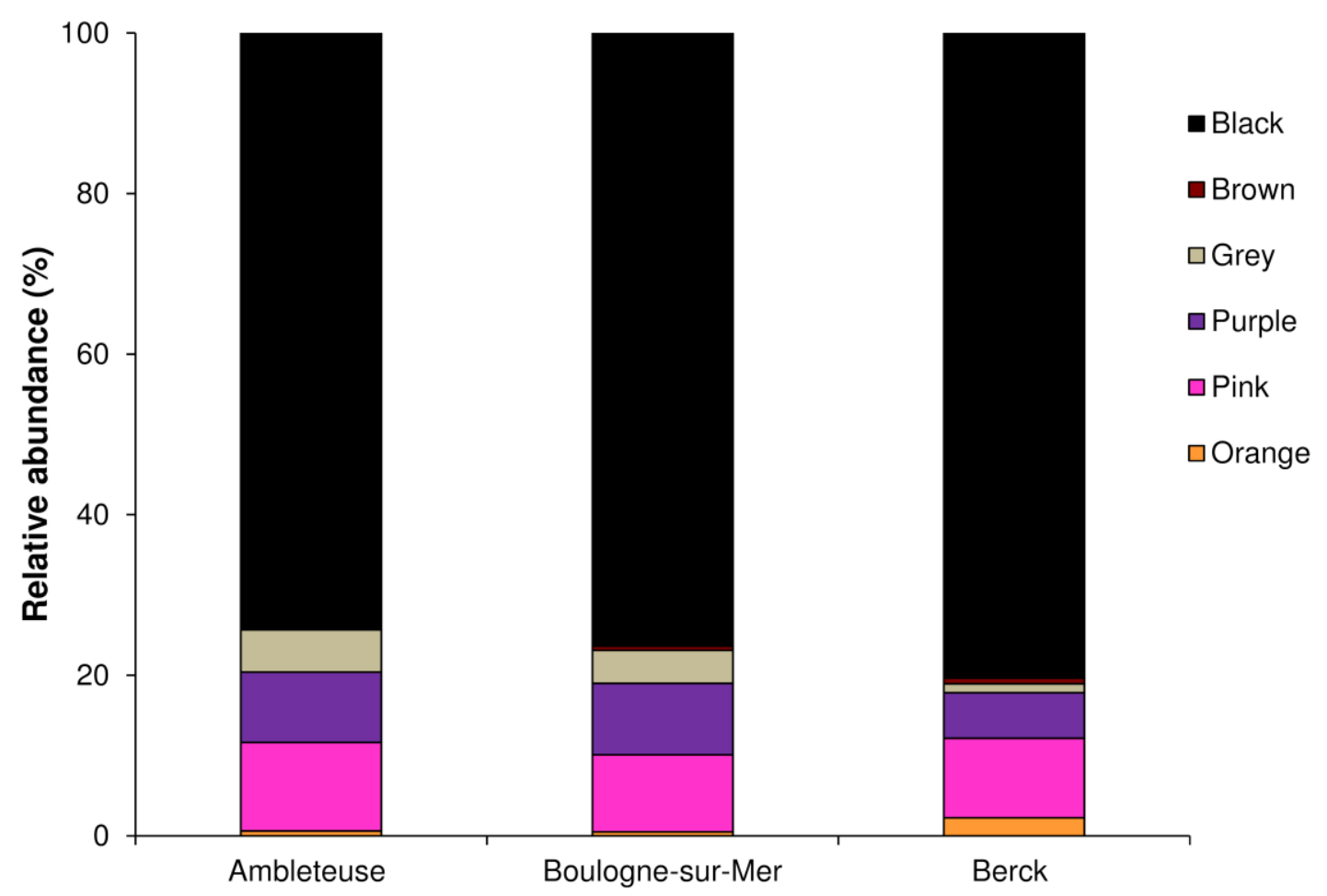

Figure 4: Proportion of particles (A) and fibers (B) per color at each station. 


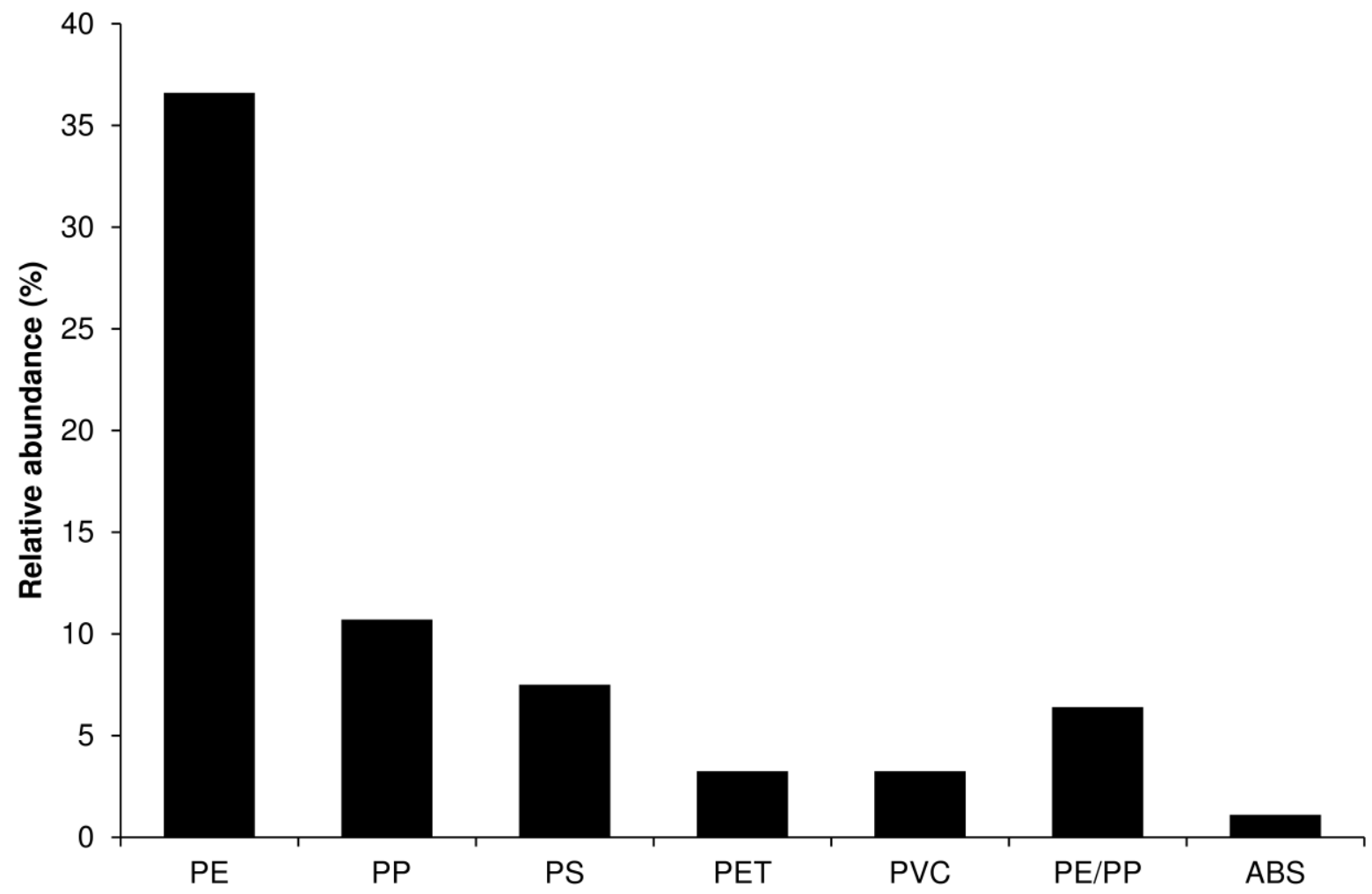

Figure 5: Relative abundance (\%) of identified polymers. 


\section{Occurrence and identification of microplastics in beach sediments from the Hauts-de- France region}

Périne Doyen $^{1, \mathrm{a}, \mathrm{c}, *}$, Ludovic Hermabessiere ${ }^{1, \mathrm{~b}}$, Alexandre Dehaut ${ }^{\mathrm{b}}$, Charlotte Himber ${ }^{\mathrm{b}}$, Marion Decodts $^{c}$, Thiefaine Degraeve ${ }^{c}$, Léna Delord ${ }^{c}$, Marie Gaboriaud ${ }^{c}$, Pauline Monéc ${ }^{c}$ Jade Sacco , Eric Tavernier ${ }^{\mathrm{c}, \mathrm{d}}$, Thierry Grard ${ }^{\mathrm{a}}$, Guillaume Duflos ${ }^{\mathrm{b}}$.

${ }^{1}$ P. Doyen and L. Hermabessiere share co-authorship of this article

a. Univ. Littoral Côte d'Opale, USC Anses, EA 7394 - ICV - Institut Charles Viollette, 62200 Boulogne-sur-Mer, France.

b Anses, Laboratoire de Sécurité des Aliments, Boulevard du Bassin Napoléon, 62200 Boulogne-sur-Mer, France.

c IUT Littoral Côte d'Opale, Boulevard du Bassin Napoléon, 62200 Boulogne-sur-Mer, France.

d Univ. Littoral Côte d'Opale, Univ. Lille, CNRS, UMR 8187, LOG, Laboratoire d'Océanologie et de Géosciences, 62930 Wimereux, France

* Corresponding author: E-mail address: perine.doyen@univ-littoral.fr.

Supplementary data

\begin{tabular}{|c|c|c|c|}
\hline & Ambleteuse & Boulogne-sur-Mer & Berck \\
\hline HTL & $\begin{array}{l}50^{\circ} 48^{\prime} 6.47^{\prime \prime} \mathrm{N} \\
1^{\circ} 36^{\prime} 13.4^{\prime \prime} \mathrm{E}\end{array}$ & $\begin{array}{l}50^{\circ} 43^{\prime} 57.41^{\prime \prime} \mathrm{N} \\
1^{\circ} 35^{\prime} 13.4^{\prime \prime} \mathrm{E}\end{array}$ & $\begin{array}{l}50^{\circ} 23^{\prime} 39.3^{\prime \prime} \mathrm{N} \\
1^{\circ} 33^{\prime} 36.7^{\prime \prime} \mathrm{E}\end{array}$ \\
\hline $\mathrm{IZ}$ & $\begin{array}{l}50^{\circ} 48^{\prime} 5.75^{\prime} \mathrm{N} \\
1^{\circ} 36^{\prime} 7.63^{\prime \prime} \mathrm{E}\end{array}$ & $\begin{array}{l}50^{\circ} 43^{\prime} 58.05^{\prime \prime} \mathrm{N} \\
1^{\circ} 35^{\prime} 30.11^{\prime \prime} \mathrm{E}\end{array}$ & $\begin{array}{l}50^{\circ} 23^{\prime} 40.7^{\prime \prime} \mathrm{N} \\
1^{\circ} 33^{\prime} 32.0^{\prime \prime} \mathrm{E}\end{array}$ \\
\hline LTL & $\begin{array}{l}50^{\circ} 48^{\prime} 5.12^{\prime \prime} \mathrm{N} \\
1^{\circ} 36^{\prime} 0.51^{\prime \prime} \mathrm{E}\end{array}$ & $\begin{array}{l}50^{\circ} 43^{\prime} 58.72^{\prime \prime} \mathrm{N} \\
1^{\circ} 35^{\prime} 26.39^{\prime \prime} \mathrm{E}\end{array}$ & $\begin{array}{l}50^{\circ} 23^{\prime} 39.7^{\prime \prime} \mathrm{N} \\
1^{\circ} 33^{\prime} 29.8^{\prime \prime} \mathrm{E}\end{array}$ \\
\hline
\end{tabular}

Table S1: GPS coordinates of the sampling sites at the different tide line: HTL $=$ high tide line; $\mathrm{IZ}=$ middle of the intertidal zone; $\mathrm{LTL}=$ low tide line, located in the three stations. 


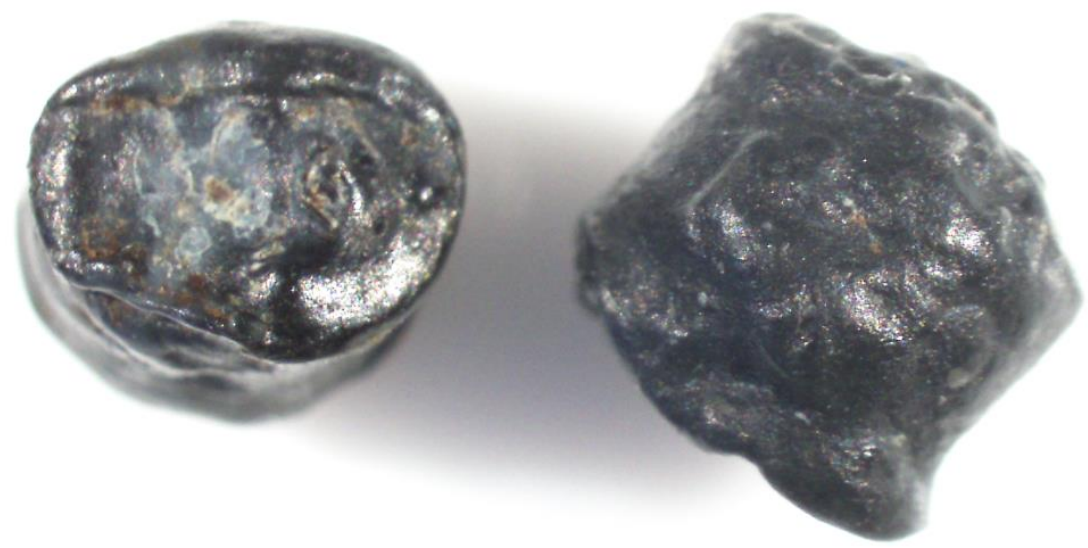

$\overline{1 \mathrm{~mm}}$

Figure S1: Black pellets found at the high tide line at Boulogne-sur-Mer. 